\title{
AUDIENCE RESPONSE OF RACISM IN HIDDEN FIGURES MOVIE
}

\author{
Rina Suarnaningsih ${ }^{1}$, Syahruni Junaid ${ }^{2}$, Nahdhiyah ${ }^{3}$ \\ English and Literature Department, Adab dan Humaniora Faculty \\ Alauddin Islamic State University of Makassar, Indonesia \\ ${ }^{1}$ Rina.mandallekang@gmail.com \\ ${ }^{2}$ Syahruni.junaid@gmail.com \\ ${ }^{3}$ nahdhiyahbaharuddin@gmail.com
}

\begin{abstract}
This study is about the audience response of racism toward Hidden Figures movie which is aimed to reveal the response of the audience about racism toward Hidden Figures Movie. This study used the reader-response theory by Louise Thursone. Data were analyzed by using interpretative qualitative method. The interview sheet is used as the instrument to find out the valid data. The study showed varied responses toward the racism of the Hidden Figures movie. The response of the audience is classified into two categories; positive and negative response.
\end{abstract}

Keywords: Response, Audience, Racism

\begin{abstract}
ABSTRAK
Kajian ini tentang respon audiens tentang rasisme terhadap film Hidden Figures yang bertujuan untuk mengungkap respon audiens tentang rasisme terhadap film Hidden Figures. Kajian ini menggunakan teori reader respon oleh Louise Thursone. Data dianalisis menggunakan metode kualitatif interpretif. Lembar interview digunakan sebagai instrumen. Hasil menunjukkan respon yang bervariasi terhadap film Hidden Figures. Respon audiens diklasifikasi kedalam dua kategori yaitu respon positif dan respon negatif.
\end{abstract}

KataKunci: Respon, peserta, rasisme.

\section{INTRODUCTION}

Racism is a racial issue in the lives of multicultural communities in various parts of the world. Racism is growing rapidly in a country as the development of technology and trade resulting in the growth of the level of pluralism in the country. Those who are constructed as superior race often commit acts of racism towards certain lower the class of races. These acts of racism occur in various areas of public life such as education, employment, health care, entertainment, and others. 
Racial issues are very sensitive in American life. It has existed in the United States since the colonial period in the present day. W.E.BDu Bois said that the problem of the U.S.A in the 20 century is about color and race. It shows that racism against AfricanAmericans and other skin colors of people has been a continuing feature of U.S society and has been becoming cultural heritage from the previous generation. Issues regarding race are very sensitive in American life and have been prominent in much public discourse in the United States. It is not only in America but also in the whole life of the world.

Racism, one of the social conflicts in the Hidden Figures movie, is a global topic in the society which is a lot of times by people. Besides becoming the topic of discussion, people can easily watch and feel it in their environment, books, and even in some of the literature. There are many people which are treated differently by other people, because of their skin color of race. Literature as the reflection of reality also shows this phenomenon and it becomes the exiting topic to be researched. It is defined that racism is the belief from some racial groups that are superior to other races, and racism has been commonly used to justify discrimination and inequality.

Hidden Figures (2016) is a movie adapted from best-seller non-fiction novels in New York, Hidden Figures: Margot Lee Shetterly's American Dream and the United States in 1961. The movie depicts how racial segregation is carried out by the American government towards the white and the black race. In this movie, it is clear how injustice is perpetrated by white people against black people as a society that holds the majority status in Virginia.

This movie tells about racism which hits black people, Besides that the movie also tells the history and great contribution of three black women who manage to realize NASA (National Aeronautics and Space Administration) and American dreams. It depicted the separation made by the American government against the white and the black race. There is a struggle of three black genius women from Africa who work at NASA where the majority of workers are white people. Katherine Goble, Mary Jackson, and Dorothy Vaughan are three great female figures from Africa who have to deal with the challenges of discrimination of white people at that time.

Literature allows the audience to access the intimate emotional aspect of a person's character that will not be obvious. 
Literature work has no meaning without reader or audience, such as literary works if it can be understood and be likely by the audience, that text is failed. Thus, literary work has a strong relationship with the readers or audience for having an important role in literary work development because the audiences are people who enjoy the literary work and they have a role in giving the meaning and appraising the literary works. Based on the explanation, the researcher is interested in studying the audience response of racism in Hidden Figures movie. The reason why the researcher chooses this study is that the problems are closely related to what happens in the reality of society. The researcher wants to know the extent of the audiences' understands of racism in the movie, by getting their response. This movie was set in 1961 and published in 2016 but it received many positive reviews from movie critics. The researchers want to know whether the idea of racism in 1961 still influenced the audience's response.

Some relevant studies focus on the reader to respond to literary works. They are (Masriah, 2016) in her thesis, "The Adult's Reception in Anime Lover Community Toward the Story of Animated Cartoon in Mashahi Kishimoto's Serial Naruto" focused on the adult's reception toward the Naruto series. She used the theory of aesthetic reception from Seger's and takes descriptive qualitative research. Next, (Harun, 2015) in his thesis, Reader response Analysis on The Other Boleyn Girl Movie. This research aims to know the audience's response and the cultural value that affects the audience's responses since the movie consist of the agreement and disagreement with different reasons. Based on their reasons, it has been found that the audience response affected by the cultural value, such as the knowledge, value, beliefs, and experience.

Another similar research is also done by (Pertiwi, 2015) in her thesis, "Response of Female Reader in Yousafzai's Autobiography I am Malala", aimed to know the response of female readers in intrinsic elements, and to know the response of female readers if they become Malala, and to find out the moral message that can be taken by female readers toward Yousafzai's Autobiography "I am Malala". She used the descriptive qualitative method and analyzed it using Thurstone's theory. 


\section{Reader Response}

The reader response is a criticism of the reader that talks a lot about the reader and the reading experience (Fowler, 1991). This argument describes the reader besides enjoying a literary work, either in the novel or in a visual form such as a movie. Reader response criticism, in modern academics, is another literary theory that focusing on the audiences or readers' experience of many literary works. The theory gained popularity because of its contrastive ideology. The traditional theories primarily focused on the form or content of the literary work.

Literary work without a response of readers or audience is a literary work that has no meaning. Because readers or audiences to give esthetic, meaning toward a literary work based on reader experience. Research about the aesthetic response is part of the literary pragmatics study includes how the reader enjoys the literary work, and how it teaches the reader. As already said by Poe (in Wallek and Warren, 1989) that the function of literary work is to entertain, and all at once to teach something.

The research of aesthetic response is more tended to be modern literary. The orientation of the research will reveal three things that are: (a) what the reader does with the literary work, (b) what the literary work does with its reader, and (c) what the limitation task of the reader as the sense giver. This is all at once which implies that actually, the reader is different from each other, and surely will receive the literary work different attitude and attention.

There are three categories of readers according to Iser as cited in (Segers, 2000) as follow:

The ideal reader is well-grounded. They are theoreticians in the interpretation process or called academic readers or critics because they understand and read many literary theories.

An implicit reader or called as the informed reader is competent. This reader usually has competence of language, semantic, or literary code enough.

Real reader, is the reader who has been in the author's mind when $\mathrm{he} / \mathrm{she}$ wrote his/her idea of the literary work, for example, the children reader arises/emerges when the author wrote about a children's story. 


\section{The horizon of expectation from (Jauss, 1982).}

It is the expectation of readers about the text of literary work that they read. The readers expect literary work that they read appropriate with what they expect or want to perceive. The horizon of expectation of reader is divided into two parts that are: first, Aesthetic, which is the reception of intrinsic element of literary work such as theme, plot language style, character, etc. second, Non-aesthetic, which is the attitude, experience, and situation, education, knowledge of reader itself, and ability to perceive the literary work.

The horizon of expectation from Jauss is more tended to the reception of the reader which developed in the historic situation of literary work toward the reader. This is mentioned in (Endraswara, 2011) that the horizon of expectation appears as the result of the historical moment of literary work. Then, (Wati, 2014) mentions that there are two types of reception as part of the horizon of expectation from Jauss they are synchronic and diachronic. Synchronic is said to analyze the literary work related to the reader in the same age or period and diachronic involve the reader throughout history after the literary work published. In this case, the researcher used the synchronic reception.

Reader response theory is about how readers give a meaning toward literary work as their reaction and response to the text. Literary work always got a response from the readers or audience. The response is utterances of the reader or how the literary work is received according to experiences. The reader also directly criticizes the literary work that they watch based on their experiences. The reading experience is the process of meaning carried out based on the imaginative experience that is gained by the reader when reading or watching the literary work. This shows that a text must have a reader who can give a certain meaning and identity after they have read or watched it. According to (Goldstein, 2005), reader-response criticism states that the interpretive activity of the reader in understanding the significance of the text and aesthetic value is not the author's task. However, this happens to the reader naturally in comparing knowledge, experience, and what they have read, witnessed. The importance of understanding the reader's responses is more focused on understanding literary texts when they enjoy certain discourses which are an exclusive feature of the literary genre (Ghandehari, 2012). Therefore, the discussion of text analysis has the potential to 
link the interpretation level of the reader that is quite high in giving meaning to the message received.

Insights and conclusions obtained by the reader are based on the background of the knowledge and experience of interpretation that the reader receives. The text that is read through novels or watched through movies is interpreted by the reader to identify the tendency of the author to make literature. This identification is intended to provide a better understanding of how meaning is created by the reader through his active involvement in reading texts. Through the reading process, a reader 'symbolizes' with the text which is followed by re-symbolization when the first act of perception and identification products in the need, desire, or demand for an explanation.

The response comes from word response; it means reply or reaction. The response is a reaction to a question, experience, or some other type of stimulus. According to (Sobur, 2003), the response is also interpreted as attitude tangible well before detailed understanding, research, influence, or rejection, like it or not, and utilization at a particular phenomenon. Seeing a group against something, thus, it will be known how their response to these conditions. According to (Susanto, 1998), the response is a reaction of rejection or acceptance which is happening to someone after receiving the message. Response to any behavior is essentially a response to the stimulus (Sarlito, 1995). While (Gulo, 1996) stated response is a reaction or an answer that depends on the stimulus or the result of the stimulus. The human individual participant the controller between the stimulus and the response so it determines the form of the individual response to the stimulus as the individual's stimulus and factor. The interaction between several factors from the outside on the form of the objects, and in the form of attitudes, death, and emotions influence and ultimately determines the form of behavior on one performs.

While ( Thursone in Nasution, 2009) classified response in two categories: a) Positive response appears if someone please, like, receive, agree, and give positive comments to an object (Soemanto, 1998). b). The negative response that occurs when a person refuses, disagree, dislike, even give a bad comment to an object (Lahey, 2003). Person response can be in good or bad form, positive or negative. When a positive response is concerned the person tends to like the approach the object, whereas the negative response tends to the move away from the object. 


\section{Racism}

Racism and discrimination have been socio-cultural constructs present throughout the United States for multiple generations. The dominant social majority maintains the hierarchal power to shape and define what they deem an "inferior population" as seen with any opposing cultural group; this can be observed with the emergence of slavery and the African-American minority (Painter, 2007). Racism has existed throughout the human story. It may be defined as the hatred of one person by another - or the belief that another person in less than human - because of skin color, language, customs, and place of birth or any factor that supposedly reveals the basic nature of the person. It has caused wars, slavery, the formation of nations, and legal codes.

Racism is generally defined as actions, practices, or beliefs that reflect that racial worldview: Ideology that is divided into separate and exclusive biological entities called "races". The ideology entails the belief that members of a race share a set of characteristics that are inherited, and that this inheritance means that races can be ranked as innately superior or inferior to others (Schaefer, 2008). Racism is identical with, prejudice, violence, discrimination, or oppression: the term can also have varying and hotly contested definitions. Discrimination is actual behavior, the practice of different and unequal treatment of other groups of people, usually along racial, religious, or ethnic lines (Parillo, 1985). He explains that racism may be defined as linking the biological condition of the human organism with its socio-cultural capabilities and behavior. From those definitions, the researcher concludes that race is a concept of grouping people according to biographical distinction and geographical area. Then racism is a condition that happens because it has certain capabilities and behavior in socialcultural, also believes that others inferior can be ruled.

\section{RESEARCH METHOD}

This study used a qualitative interpretive method to analyze and interpret the response of the audience toward racism. Departing from an effort to find an explanation of cultural events from the qualitative interpretive methods based on the perspectives and experiences of the person being studied. An interpretive approach is adopted from a practical orientation. Generally, the interpretive approach is a social system established 
behavior in detail directly observing (Newman, 1997). This study used accidental sampling. As explained by, (Gulo, 2002) that the sampling and non- probability sampling is generally used for a study population is not known. That is, accidental sampling is a sampling procedure that selects samples, people, or units that are most easily found or accessed.

The subject of this study are students of the English literature department who have watched the Hidden Figures movie, and gave opinion or perspective. They are selected randomly by accidental sampling technique. The researcher found as many as 12 participants, that are included, female and male. The researcher did this research for 5 weeks to arrange the research and collect the data from the participants because the audiences are in a different background.

This study used an interview sheet to interview the audience to explore racism and to find responses to that situation to be analyzed. The data collector would-be participant, too. The interview guideline sheet is adapted from (Pertiwi, 2015). The data are collected in July 2019. Some questions that the researcher asked the participants are about their opinion about racism and the struggle of the main character in the Hidden Figures movie in facing the situation. The research also asked about the particular action that they will do if they are the characters in the movie and the moral message they got from the movie. The steps of collecting data started from identifying the audience who have watched the movie, selecting the audience who are from English and Literature Department by accidental sampling, and interviewing them by using interview sheet asking about their responses of racism and the moral message that they found after watching the movie "Hidden Figures" 2016 and transcribe the result of the interview that was recorded. The researcher used Thursone's theory to analyzed the response of the audience, where he divides responses into two categories; positiveand negative response.

\section{FINDING AND DISCUSSION}

The findings show that there are different answers from different audiences with different backgrounds that result in a different meaning of literary work interpretation. In one literary work, the audience catches different meanings. There are various 
kinds of responses toward racism obtained by the audience in the Hidden Figures movie. Racism obtained is based on the results of the audience experience while watching a movie, then from the results of the viewing experience, the audience focuses on providing information in the movie so that they can respond to the movie.

There are two varieties of answers that the audience thinks about the Hidden Figures movie. The first, most of them said that Hidden Figures are racist movies, where the racism in this movie is very clear and frontal while we know that this movie is created based on a true story in the history of America against racism. It shows how the lives of black minorities in America when there is an isolation of their race. On the other hand, discrimination against the black race is happening even in public areas. It can be seen that many scenes that show public colored facilities for the black race and uncolored for the white race. Not only public facilities, but discrimination also occurs in the realm of education. The second, audience thought that Hidden Figures is a movie that tells the story of three black female figures namely, the first figure is an aeronautical engineer at the first at NASA, the second is a first female supervisor at NASA, and the third is the first woman dedicated computing space because of his services. The three black women in this movie exert themselves to show their potentials and abilities. They were struggling against racism. Some scenes show that. For example, when one of the women is trying to realize her dream of becoming a field engineer was hindered because she was not a graduate of Hampton High School. To combat this act of discrimination, she petitioned the court to get a chance to continue her school. The other struggle against racism can also be seen when another main character had to leave for 40 minutes just to make water because there were no restrooms available for black women. Discrimination of white people toward black people was becoming harder when they see the potential of blacks.

Based on the explanation above, it is showed that the respondents' answers show a positive response because they give positive comments to the movie Hidden Figures. Audience response to Hidden Figures movies is referred to as positive comments according to (Soemanto, 1998). The positive response appears if someone please, likes, receives, agrees, and gives positive comments to an object.

The responses of the audience about the struggle against racism show that the audience agrees about the character's 
action. Most of the reasons for the audience agree because the three main characters are dared to fight racism and survive to get the rights. They thought that the three main characters experienced discrimination and segregation; they dared to take the fight through their intellectuality against discrimination by showing their achievements. Meanwhile, the audience also showed positive responses because the three main characters keep surviving amidst the conflict. As we know that American society still strongly discriminates against black people by applying segregation between whites and blacks. In this movie, blacks have difficulty getting an engineering degree and must get permission from the judge to be able to attend classes that are all white people. They experienced a lot of pressure such as submissions that are always rejected, even many people doubt their abilities because they are women and black that makes them unreliable. The next reason is that the main player Marry Jackson shows a woman's bravery in education which she became the first black student at the school.

Based on the explanation above, the researcher concludes that the respondents' answers are showing different interpretations but basically, all of their answers were supporting the struggle of the females figure in the movie against the racist situation they were facing, so they are categorized as a positive response. The varieties of answers from the audience could be briefly explained as follow: most of the audience answered that they will do the same as the main characters do. It is because the three main characters are figures that inspire people. They are so brave fighting for the injustice, striving to prove and show the potential and expertise they have. They use their intelligence to fight for their rights. Another audience also thought that they might not do the same as the main characters do because he was a type of a submissive person and did not dare to rebel. The other similar response of the respondents said that he was not sure of doing the same in that condition because he is not a great survivor if he has to be in the State with black citizens.

The findings above become proof that generally respondents' answers are positive responses because they support what the three main characters do if they are in the same situation and the figures' struggles are inspired them. Furthermore, the interview results about the moral message that they get from the Hidden Figures movie show that the respondents believe that as a human being, everyone is entitled 
to get rights and should fight for that. If every people understand their right, they may not be afraid to fight back. Moreover, one of the respondents explained that the right that they mean here is right for education. It is then found that the respondents understand that humans entitled and should get an education without prohibition from other people because education is an important thing for a human being without any exception.

The audience's response to the struggle against racism in the movie is good and inspired them. The Hidden Figures movie brought the interest of the audience because of the interesting storyline and conflict that succeed arising particular tension in their feeling. The Hidden Figures gave influence to the audience emotionally. The audience took lessons from the movie and made them know as well as look for further about racism and American culture.

\section{CONCLUSION}

This study showed that there are many kinds of audience responses to every question that has been given to the audience. The responses are classified based on the agreement and disagreement of the audience toward the question and some reasons why the audience responded to it. The findings and discussion showed the moral value that affects the audience's response.

\section{BIBLIOGRAPHY}

Charmichael, Stokely \& Charles V. Hamilton, (1967). Black Power: The Politics of Liberation in America. America.

Endraswara, Suwardi. (2011). Metode Penelitian Sastra. Yogyakarta: CAPS.

Fokkema, Douwe and Eldruc Ibsch. (1977). Theories of Literature in The Twentieth Century: Structualism, Marxism, Aesthetic of Reception, Semiotics. United Kingdom: C.Hurst\&Co.

Ghandehari, Shaghayegh. 2012. Definition of Reader, as a Relative Concept, in Reader-Response Theories. NY: Elsevier Ltd.

Goldstein, Philip. (2005). Reader-Response Theory and Criticism. Maryland: John Hopkins University Press.

Gordon, Lewis. (2000). "What Does It Mean to Be a Problem?: 
W.E.B Du Bois on the study of Black Folk," In Lewis R. Gordon(ed.), Existential Africana: Understanding Africana Existential Thought, New York: Routledge.

Gregory, Guest, and Elizabeth. (2012). Collecting Qualitative Data: A Field Manual for Applied Research Paperback. United State of America: Sage Publication Inc.

Gulo, W. (1996). Metodologi Penelitian. Jakarta: PT Grasindo.

Gulo, W. (2002). Metodologi Penelitian. Jakarta: Grasindo Indonesia. Harun.2015. Reader response Analysis on The Other Boleyn Girl Movie. Alauddin State Islamic University of Makassar.

Holland, N. (1980). Unity, Identify, Text, Self. In J. P. Tompkins (Ed.), Reader Response Criticism: From Formalism to PostStructuralism. (pp. 118-133). Baltimore: John Hopkins University Press.

Inayah, Farida. (2012). Representation of Racism in Novel The Help by Kathryn Stockett. Alauddin State Islamic University Of Makassar

Isaac, S, and Michael, W. (1987). Handbook In Research and Evaluation for Education and The Behavioral Sciences. San Diego: Edits Publisher.

Jauss, H. R. (1982). Toward an Aesthetic of Reception. (T. Bahti, Trans.). Minneapolis: University of Minnesota Press.

Kenneth Neubeck, Alice Mary. (1997). Social Problem: A Critica Approach. USA: McGraw Hills Company.

Lauer, Robert H, and Lauer, Jaenette C. (2006). Social Problem and Quality of life. United States. McGraw-Hill

Lahey, Benjamin. (2007). Psychology an Introduction Ninth Edition. New York: McGraw-Hill.

Masriah. (2016). The Adult's Reception in Anime Lover Community Toward the Story of Animated. Cartoon in Mashahi Kishimoto's Serial Naruto. Alauddin State Islamic University of Makassar.

Nasution, Hetti Suaida. (2009). Respon Karyawan PT.Tirta Lyonnaise Medan Terhadap Program Jamsostek. Unpublished Thesis. Medan. Universitas Sumatera Utara.

Newman, W.L. (1997). Social Research Method Qualitative and 
Quantitative Approach. Boston: Allyn and Bacon.

Parillo, Vincent. (1985). Stranger to These Shores, Race, Ethnic Relation in The United States. New York: Macmilan Publishing Company.

Pertiwi, Gianti. (2015). Response of Female Reader Response Yousafzais Autobiography I am Malala. Alauddin State Islamic University of Makassar.

Sarwono, Sarlito Wirawan. (1995). Teori-Teori Psikologi Sosial. Jakarta: PT Raja Grafindo Persada.

Segers, Rien .T. (2000). Evaluasi Teks Sastra. Translated by Suminto A Sayuti. Yogyakarta: Adicita Schaefer, R. 2008. Encyclopedia of race, ethnicity, and society. United States:Sage Publication.

Selden, R. (2005). Reader-Oriented, in W. Peter (Eds.), A Reader's Guide to Contemporary Literary Theory. Hertfordshire: Harvester Wheatsheaf.

Sobur, Alex. (2003). Psikologi Umum. Bandung: Pusaka Setia. Soemanto, Wasty. 1998. Psikologi Pendidikan. Jakarta: Rineka Cipta.

Susanto, Astrid S. (1998). Komunikasi Sosial di Indonesia. Jakarta: Bina Cipta.

Teew, A. (1984). Sastra dan Ilmu Sastra "Pengantar Teori Sastra. Jakarta Pusat: Dunia Pustaka Jaya.

Trisnawati, Ririn Kurnia. (2016). Implementing Reader-Response Theory: An Alternative Way of Teaching Literature Research Report on the Reading of Bookers Washington's Up from Slavery. University Brunei Darussalam

Tyson, Luis. (2006).Critical Theory Today. New York: Taylor and Francis Group.

Wacquant. (2002). Racism: A Short Story. United States America: Princeton University Press.

Wati, Tita Purnama. (2014). Resepsi Siswa Terhadap kumpulan puisi "Aku Ini Binatang Jalang" Karya Chairil Anwar. Yogyakarta: Universitas Negeri Yogyakarta.

Wellek, Rene dan Warrem, Austin. (1989). Teori kesusasteraan. Jakarta: PT. Gramedia.muslims-across-china-are-living-in-fear 